\title{
Attention to health in federal budget "disappointing"
}

$\mathrm{T}$ he 2013 federal budget stays the course on health care spending, with no cuts to transfer payments to the provinces for health and social programs, few perks for Canadian families and a heavy focus on creating jobs by boosting infrastructure projects and assisting the manufacturing sector.

"The theme of course is jobs, growth and long-term prosperity," Finance Minister Jim Flaherty told reporters just prior to releasing the budget in the House of Commons March 21. He identified skills training, support to manufacturing and innovation, and infrastructure as the three pillars of his action plan, which he said reflected Canadians' priorities.

Despite those initiatives, the budget keeps commitments agreed to in the 2004 federal-provincial health care agreement, the 10-Year Plan to Strengthen Health Care. Under that agreement, transfer payments for health will increase by $6 \%$, with only modest health care initiatives for targeted sectors like Aboriginal mental health.

That $6 \%$ increase was difficult for the federal government to achieve, Flaherty told reporters, and comes at the expense of keeping the federal government's own program spending flat.

"We're increasing health care spending by $6 \%$, and most of the provinces are only increasing their spending by, on average, $3.1 \%$," Flaherty pointed out. "We made reductions in our own spending."

As expected, this budget also signals the end of transfers to provinces for the wait-time reduction program, a 10-year plan to reduce patient waiting times in critical areas such as joint replacement, cancer treatment, cardiac care, diagnostic imaging and sight restoration. The plan ends in 2014/15.

Canadian Medical Association (CMA) President Anna Reid says the relative paucity of attention to health care in the budget is "disappointing."

"I'm not sure that there's a good

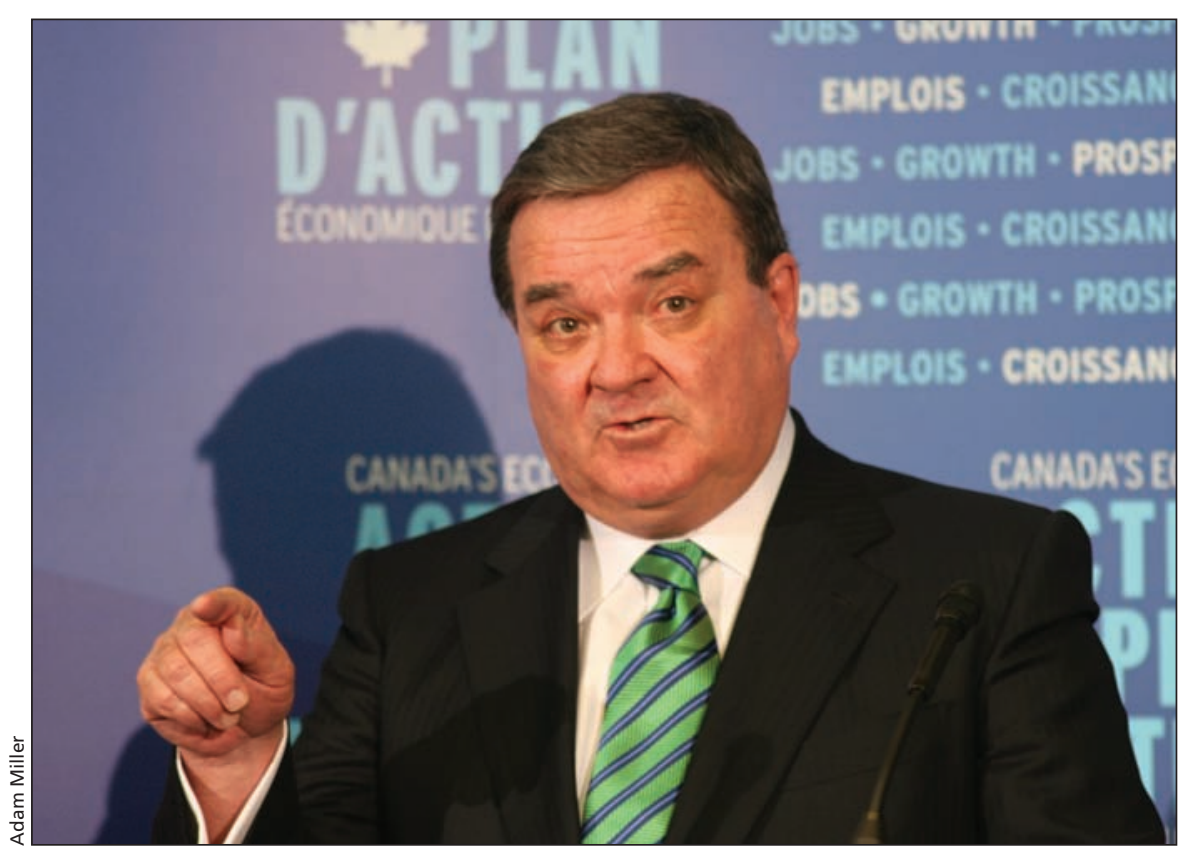

The federal budget emphasizes "jobs, growth and long-term prosperity," says Finance Minister Jim Flaherty.

understanding that healthy Canadians are the key to a healthy economy," she added. "We've been trying to make this point that you cannot have a healthy economy and a productive country unless you have highly functioning healthy Canadians."

Among the few health care initiatives are:

- \$48 million over two years to improve telehealth and videoconferencing technology as well as electronic health records in First Nations communities;

- \$4 million over two years to increase the number of mental health wellness teams serving remote First Nations, likely adding four teams to the existing seven;

- \$3 million for palliative care training for primary care professionals, delivered through the Pallium Foundation of Canada;

- GST/HST exemption at point-of-sale on provincially subsidized homecare services for seniors or the disabled, and on the accompanying medical supplies; and
- A doubling of the existing taxes on manufactured tobacco products, such as snuff, chewing tobacco and loose tobacco, to keep taxation of these products on par with cigarettes.

In contrast to Reid's assessment, Minister of Health Leona Aglukkaq said the budget "had significant investments for health care."

"Transfers to provinces and territories are at record highs and continue to grow," she says. In addition there are new investments in palliative care, patient-oriented research, First Nations and Inuit health and other areas.

"To do all this, while still staying on track to balance the federal books by 2015 , shows that our government continues to play a leadership role in health care," says Aglukkaq.

In a fiscal climate buffeted by a fragile global economy and a slowerthan-anticipated recovery in the United States, "there are still signs of trouble ahead," Flaherty warned in his budget speech to the House of Commons, even as he pledged to meet his target of balancing the budget in 2015. "The 
world economy remains fragile. Global growth has slowed. And Canada is not immune."

Flaherty acknowledged that "Economic Action Plan 2013 contains the smallest increase in discretionary spending in nearly 20 years."

The centrepiece of the budget is a Canada Job Grant program that provides employers with $\$ 5000$ per person to provide skills training to employees at a qualified institution. Employers have to contribute another $\$ 5000$, and the provinces must add a further $\$ 5000$ per person in matching funds, for a total \$15000 grant to train someone for a new or existing job.

Acknowledging both the jobcreation potential and the reality of Canada's aging infrastructure, the budget also contains $\$ 47$ billion in new money over 10 years, beginning in 2014/15, for roads, public transit, recreational facilities and community projects, as well as other major economic infrastructure projects.

Reid said the CMA is "pleased" to see funding for infrastructure, "but we wish that some of it had been actually targeted towards health care infrastructure." She said she hopes this will come in the next year. With an aging population, she is particularly concerned about infrastructure spending for long-term care facilities. "We don't have an over- all plan of how we're going to address their needs."

The federal government also acknowledges investments in research and development as critically important to Canada's future economic growth. The budget includes more than $\$ 1$ billion in new spending for research and development, including \$165 million to Genome Canada, \$225 million to the Canada Foundation for Innovation, \$325 million to Sustainable Development Technology Canada, $\$ 141$ million to the National Research Council, \$141 million to Atomic Energy of Canada Limited, and an additional $\$ 37$ million to the three federal granting councils.

In addition, the budget supports harmonizing requirements for apprentices to try to make their skills more transferable across provincial borders, and puts $\$ 70$ million over three years into a paid internship program for postsecondary graduates.

The major tax relief in the budget is for manufacturing companies to invest in more modern machinery and equipment, as well as an expansion of the temporary hiring credit for small business, a \$50 000 increase in the lifetime capital gains exemption for the sale of small business corporation sales and qualified farm and fishing property.

"We could have done more," Flaherty acknowledged in a news conference prior to releasing the budget. "In our view it was not necessary to do more."

The federal government is also putting more money into social housing, with a $\$ 1.25$ billion investment $\$ 235$ million per year for five years for the Investment in Affordable Housing program. Provinces and territories can use that money to build new housing or to renovate housing, for home ownership assistance, rent supplements, shelter allowances and accommodations for victims of domestic violence.

The budget also provides $\$ 600$ million- $\$ 119$ million per year for five years - to Housing First services that provide people from shelters and the streets affordable housing, while providing them with support for underlying mental health or addiction problems.

In other measures, the budget outlined the government's plans to improve foreign credential recognition processes, and injected \$23 million over two years to market Canada to foreign students, to attract promising students from around the world to Canadian postsecondary institutions, and to allow Canadian students to study abroad. The government is also beefing up its capacity to process visas for international students and others studying and working in Canada. Adam Miller, CMAJ

CMAJ 2013. DOI:10.1503/cmaj.109-4446 